811.163.41'373.7

811.112.2'373.7

https://doi.org/10.18485/sj.2020.25.1.23

ГОРДАНА М. РИСТИТ

Универзитет у Новом Саду

Филозофски факултет
Оригинални научни рад

Примљен: 15. 10. 2019.

Прихваћен: 15. 01. 2020.

\title{
КОНЦЕПТУАЛИЗАЦИЈА ТУГЕ У НЕМАЧКИМ И СРПСКИМ СОМАТСКИМ ФРАЗЕОЛОГИЗМИМА
}

У раду се анализира концептуализација туге у немачким и српским соматским фразеологизмима. Истраживани материјал подвргнут је концептуалној анализи, с циљем да се постулишу когнитивни механизми из домена туге, и контрастивној анализи, која за циљ има утврђивање типова еквивалентности са формалног и семантичког аспекта. Полазимо од претпоставке да ће концептуализација ТУГЕ на корпусу немачких и српских соматских фразеологизама показати углавном сличности, али и културолошки условљене разлике.

Кључне речи: фразеологизам, соматизам, еквивалентност, појмовна метафора и метонимија.

1. УВОД. Рад припада области контрастивне и когнитивне лингвистике и бави се концептуализацијом туге у немачким и српским соматским фразеологизмима. Концептуализација емоција, па и туге била је предмет истраживања у многим језицима (Кевечеш 2003; Барселона 2000; Чен 2007), а код нас су се овом темом бавиле Драгићевић (2006: 309-325) и Штрбац (2018: 120-128). Полазиште за наш рад представљају теоријске поставке когнитивне лингвистике и приступа који утемељују Лејкоф и Џонсон, на основу којих се појмовна метафора и метонимија сматрају основним когнитивним

"gristic@ff.uns.ac.rs 
механизмима помоћу којих разумемо свет око себе и као такве погодне су и за вербализовање емоција. У раду полазимо и од претпоставке да су појмовне метафоре и метонимије из концепта туге у великој мери универзалне те, у том смислу, и сличне у немачком и српском језику.

1.1. Предмет нашег рада чине соматски фразеологизми из домена туге у немачком језику у поређењу са еквивалентним фразеологизмима у српском језику. Когнитивисти су мишљења (уп. Кевечеш 2010: 18) да је људско тело најчешћи изворни домен у настанку метафоричког значења у свим језицима и културама и да су појмовне метафоре утемељене у човековом телесном искуству. Соматизми, као вишелексемски спојеви стабилне структуре и значења и релативно устаљеног лексичког састава, идиоматичне конструкције, код којих је једна од компоненти назив за део људског тела, органа, а по некима и телесне течности и који углавном означавају човекове психичке и физичке особине представљају фразеолошку и језичку универзалију као саставни део сваке културе (Мршевић Радовић 1987: 30; Раздобудко Човић 2003: 9).

1.2. Концептуализација емоција реализује се помоћу когнитивних механизама: појмовне метафоре и метонимије који омогућавају лакши когнитивни приступ апстрактнијим циљним доменима. Метафора, као феномен мишљења, подразумева средство за разумевање једног појма помоћу другог, односно пресликавање појмовне структуре с изворног на циљни домен (Лејкоф/Џонсон 1980: 5; Лејкоф 1993: 206-207). Као изворни домени појављују се конкретни појмови као што су људско тело, животиње, биљке и сл., а као циљни домени апстрактни појмови (Кликовац 2004: 7; Кевечеш 2002: 15-20). Метонимију карактерише референцијална функција: омогућава нам да користимо један ентитет уместо другог унутар истог домена, тј. један појмовни домен се концептуализује обично помоћу неког његовог дела (Кевечеш 2010: 173; Лејкоф/Џонсон 1980: 36). У великом броју радова расправља се и о начину мотивисаности фразеологизама (Доброволски 1995/1997/2009, Лејкоф 1987, Кевечеш/Сабо 1997), при чему се истиче да већина фразеологизама настаје путем метафоре и метонимије, али се наглашава и проблем разграничавања појмовне метафоре и метонимије, као и питање метонимијски мотивисаних метафора тако да неки аутори уводе појам метафтонимије која представља здружене метафоре са метонимијом (Драгићевић 2007: 91; Хосенс 19901). Кевечеш (2008: 382) наглашава да у основи многих метафора типичних за емоције лежи управо појмовна метонимија.

Лејкоф и Џонсон (уп.1980/2007; Кликовац 2004: 23; Драгићевић 2007: 91) разликују три врсте појмовне метафоре: структурне (један метафорички концепт структурира се помоћу другог), оријентационе (почивају на простор-

\footnotetext{
${ }^{1}$ Појам метафтонимије као заједничког деловања метафоре и метонимије први пут се дефинише у раду Луиса Хосенса (Хосенс 1990).
} 
ним односима) и онтолошке метафоре (разумевање емоција, идеја и сл. преко различитих ентитета или супстанција).

2. КОРПУС, ЦИЉЕВИ И МЕТОДЕ ИСТРАЖИВАњА. КорПус садржи минимална концептуална окружења, јер се у раду не бавимо квантитативном анализом, те смо га сачинили на основу одговарајућих једнојезичних и двојезичних семасиолошких и ономасиолошких речника немачког и српског језика (Дуден 2012; Милер 2005; Рерих 1991-1992; Вајнбергер 2012; Шеман 1991; Шеман 2011; Матешић 1982a; Матешић 1982b; Мразовић 1981; Оташевић 2011; РМС). Циљеви нашег рада су концептуална и контрастивна анализа емоције туге у немачким и српским соматским фразеологизмима, што подразумева постулисање појмовне метафоре и метонимије које су мотивисале настанак фразеологизма, њихов контрастивни опис и утврђивање типова еквивалентности, при чему је немачки полазни, а српски циљни језик.

У анализи смо применили модификован Бургеров контрастивни модел (Бургер: 1982) на основу којег разликујемо 1) фразеологизме са потпуном еквивалентношћу, 2) фразеологизме са парцијалном еквивалентношћу у којима су заступљене лексичке, морфосинтаксичке и семантичке разлике, 3) фразеологизме са семантичком еквивалентношћу 4) фразеологизме са парцијалном семантичком еквивалентношћу које карактерише нешто другачији лексемски састав, морфосинтаксичка структура и делимично подударна слика и 5) фразеологизме са нултом еквивалентношћу.

3. КОНЦЕПТУАЛНА АНАЛИЗА ФРАЗЕОЛОГИЗАМА. Према Речнику српскохрватског књижевног језика (РМС) туга се дефинише као „душевни бол изазван неком несрећом или великом чежњом, душевна патња, жалост. За концептуализацију туге, као и осталих емоција, битна је веза између физиолошких и бихејвиоралних испољавања емоција и појмовних метафора, нпр. физиолошке промене које се манифестују на телу и на лицу, специфичан израз лица и поглед усмерен надоле као и погнуто држање тела, промене у гласу, и напослетку и плач као прототипична реакција на тугу. Туга спада у примарне емоције које имају универзалне обрасце изражавања, а њихова вољна контрола културно је условљена (Екман 2011: 37-53). Сматра се пасивном емоцијом, доживљавач туге пасивно трпи, те стога фразеологизми из домена туге одсликавају емоционално стање човека које је изазвано неким непријатним догађајем или несрећом, и углавном су то фразеологизми са компонентом срце. Емоције су локализоване углавном у пределу грудног коша, а типични садржатељи емоција су срце и душа (Кликовац 2004: 207).

Концепт туге (Штрбац 2018: 121) обухвата „тугу као унутрашњи процес, носиоца туге или доживљавача, изазивање туге, испољавање емоције, најчешће плакањем и црте личности остварене као (не)способност да се осети туга". У нашем раду туга представља хипероним за негативне емоције сродне тузи 
у дијапазону од сете, потиштености, безвољности па све до туге. Концептуалном анализом постулисане су следеће појмовне метафоре у семантичком пољу ТУГА.

3.1.ТУГА ЈЕ ТЕРЕТ. Структурна појмовна метафора ТУГА ЈЕ ТЕРЕТ 2 постулисана је у немачким и српским фразеологизмима са соматизмима срце и груди. У њиховој позадини налазимо слику особе опхрване тугом која се поима као притисак, терет или тежина на срцу и грудима. Туга се попут терета носи, али и вуче са собом (Драгићевић 2006: 313). Срце је локализовано у грудима, а представља најважнији орган нашег тела и центар духовних и емотивних осећања и њиме метонимијски означавамо човека. Под тежином срце не ради добро те тиме угрожава људску егзистенцију. У нашем корпусу срце и груди концептуализовани су појмовним метонимијама СРЦЕ/ГРУДИ ЗА ОСЕЋАЈЕ и ЗА ЧОВЕКА . Потпуна еквиваленција утврђена је у фразеолошком пару нем. jmdm ist schwer ums Herz и срп. тешко је коме при сриу са значењем „бити тужан, жалостан, снужден, забринут." Фразеологизам из концепта несреће којим се описује особа оптерећана бригом и теретом или особа која нешто нерадо чини нем. schweren Herzens има свој потпуни еквивалент у српском језику тешка сриа. Парцијални еквивалент са сличном семантиком нем. jmdm ist das Herz schwer и срп. срие мy је отежало мотивисан је на сличан начин као и претходни фразеологизми.

Само у немачком језику постоји и каузативна варијанта овог фразеологизма jmdm das Herz schwer machen у значењу „ражалостити, обеспокојити некога" (Мразовић/Приморац 1981: 413). Као могући преводни еквивалент Матешић (1988: 541) наводи фразеологизам свалити се некоме на срие у значењу „узнемирити кога, постати нечији узрок бриге, а и боли”. За немачки фразеологизам einen Stein auf dem Herzen haben са значењем „имати великих брига, бити потиштен” утврдили смо у српском језику потпуни еквивалент имати камен на сриу (на души) и парцијалне еквиваленте камен лежи коме на сриу (на души) и компаративни фразеологизам лежати коме као камен на сриу.

Фразеологизам пада терет на груди некоме са значењем „обузима брига некога, јако је узнемирен” нема одговарајући фразеолошки еквивалент у немачком језику па је утврђена нулта еквивалентност. Мотивисан је као и претходни фразеологизми непријатношћу због осећаја тежине и притиска у грудима узрујане и узнемирене и посредно тужне особе. Као преводни еквивалент у речницима се наводи фразеологизам са компонентама туга/брига нем. jmdn befällt Trauer/Sorge (некога спопада туга/брига).

${ }^{2}$ Појмовну метафору ТУГА ЈЕ ТЕРЕТ посматрамо као део генеричке појмовне метафоре ЕМОЦИОНАЛНЕ ТЕШКОЋЕ СУ ТЕРЕТИ оДНосно метафоре ТЕШКОЋЕ СУ ТЕРЕТИ (Кевечеш 2003: 45). 
3.2.ТУГА ЈЕ ДОЛЕ. Појмовна оријентациона метафора ТУГА ЈЕ ДОЛЕ спада у типичне појмовне метафоре за концептуализацију туге (Драгићевић 2006: 310-311, Кевечеш 1998: 130). Почива на просторним релацијама са изворним доменима горе/доле или унутра/споља, напред/назад и утемељена је у нашем искуству, на основу кога положај тела повезујемо са негативним емоцијама ${ }^{3}$ нпр. када смо тужни или несрећни ходамо погнуте главе, покуњеног носа, са скрушеним изразом на лицу. Фразеологизми из нашег корпуса који почивају на овој метафори гестовног су порекла (уп. Ристић 2013: 369-378), а у свом лексичком саставу имају именице глава, нос и брк(ове) и означавају манифестацију туге. За особу која осећа тугу, сету, незадовољство и сл. утврђени су парцијални еквиваленти нем. den Kopf hängen lassen и срп. погнути/обесити/оборити/покуњити главу. Варијанте у српском фразеологизму условљене су синонимним глаголским компонентама. И наредни фразеолошки пар са незнатном морфолошком разликом почива на истој мотивационој слици нем. die Nase hängen lassen и срп. обесити нос у значењу „изражавати незадовољство, тугу, сету".

Парцијална лексичка разлика уочена је у следећем фразеолошком пару: нем. mit langer/hängender Nase abziehen и срп. отићи покуњена носа са значењем „отићи тужан, покуњен, разочаран и сл.”. У немачком језику заступљена је лексема lang (дуг), а у српском покуњен, међутим, постојећа лексичка разлика није се одразила на семантички ниво. У српском језику постоји и варијанта остати дуга/покуњена носа.

Полисемичан фразеолошки пар са установљеном потпуном еквивалентношћу нем. gesenkten Hauptes и срп. покуњене главе са значењем „потиштен, незадовољан, посрамљен” појављује се у више негативних емоција: туга, незадовољство, стид и понизност.

Тугу карактерише опште смањен мишићни тонус, опуштеност удова, повлачење и одсуство реакције (Екман 2003: 61), што бисмо илустровали нашим наредним примером са компонентом лице, који је пример за нулту еквивалентност и постоји само у немачком фразеолошком фонду ein langes Gesicht machen са значењем умусити се $e^{4}$ и који нема одговарајући еквивалент са соматизмом у српском језику.

Пример за нулту еквиваленцију налазимо и у српском језику, где је утврђен фразеологизам обесити (опустити) брк (брке, бркове). Фразеологизам је мимичког порекла, а мотивисан је сликом тужне особе којој су рубови бркова усмерени на доле (уп. Хрњак 2005: 34).

${ }^{3}$ Негативне и непријатне емоције углавном се концептуализују метафором НЕГАТИВНА/ НЕПРИЈАТНА ЕМОЦИЈА ЈЕ ДОЛЕ.

${ }^{4}$ У разговорном језику фреквентан је синонимни фразеологизам отромбољити фаиу. 
Као што је већ наглашено емоција туге концептуализована је појмовном оријентационом метафором ТУГА ЈЕ ДОЛЕ која је мотивисана типичним телесним манифестацијама туге и њој блиских емоција, те стога закључујемо да почива на метонимији. Когнитивисти се углавном слажу да су неке појмовне метафоре утемељене на појмовној метонимији, док Барселона ${ }^{5}$ тврди да су све метафоре метонимијски условљене и то објашњава управо овом појмовном метафором (Драгићевић 2006: 311).

3.3. ТУГА ЈЕ ТАМА. Туга се концептуализује као ТАМА у негативним и непријатним емоцијама, јер оно што је тамно или мрачно перципира се као лоше и негативно. Тужну особу прате и лоше и црне мисли, а њену физиономију видимо и доживљавамо као смркнуту и мрачну (Драгићевић 2006: 311-312). У нашем корпусу ова појмовна метафора идентификована је само у два фразеологизма: нем. jmds Stirn umwölkt sich и jmds Stirn verdürstet sich са парцијалним еквивалентом у српском језику навукао се облак на чело некоме са значењем „намргодити се, намрштити се”. Настали су семантичком транспозицијом нефразеолошке базне синтагме (уп. Мушовић 2002: 243) активирањем секундарног значења лексеме облак, при чему је соматизам чело концептуализован као небо, а емоција као тамни облак, односно тама.

3.4. ТУГА ЈЕ СМРТ. Туга и њој сродне негативне емоције повезане су и са доменом смрти. Фразеологизам носити мртву главу у значењу „бити утучен, потиштен” забележен је само у српском језику. Настао је метафоризацијом нефразеолошке базне синтагме (Мушовић 2002: 243). Соматизам глава концептуализован је као БИЋЕ, а емоција појмовном структурном метафором ТУГА/ПОТИШТЕНОСТ ЈЕ СМРТ која је метонимијски условљена, с обзиром на то да и туга и смрт припадају истом домену.

3.5. ТУГА ЈЕ НАСИЛНИЧКА ФИЗИЧКА СИЛА ИЛИ ТУГА ЈЕ НЕПРИЈАТЕЉ/ЕНТИТЕТ који физички насилно делује на субјекта. Туга напада, стеже или притиска човека, али је он прима пасивно, туга је емоција која не наводи на акцију и обавезно представља надмоћног непријатеља (Драгићевић 2006: 313). Фразеологизми су формирани искључиво око соматизма срце. Метонимијску основу треба тражити управо у вези између саме емоције и начина на који се она испољава, а то је најчешће непријатан осећај који се јавља у пределу срца (Штрбац 2018: 125), што наводи на закључак да су појмовне метафоре у овој групи метонимијски условљене.

${ }_{5}^{5}$ Барселона (2003: 43) то објашњава на следећи начин: физиолошке реакције као што су опуштен положај тела, опуштена рамена, погнута глава, спефични израз лица представљају бихејвиорални ефект туге и омогућавају тзв .метонимије „ефект/последица за узрок”. Надаље закључује да је за концептуализацију емоција од нарочитог значаја релација између њих и телесних манифестација до којих доводе. 
Потпуне еквиваленте представљају фразеологизми нем. jmdm bricht das Herz (vor Kuтmer) и срп. пуца/препукло је срие некоме (од туге, јада) са значењем ,јако се ражалостити, растужити, осећати јак душевни бол, умрети од туге". Њихов настанак мотивисан је сликом особе која осећа тешку, интензивну тугу, жалост, јак душевни бол па чак и умире од последица велике туге. Глаголска компонента са денотативним значењем пући/пуцати подразумева одвајање делова целине од ње саме, па се туга поима и као деловање унутрашње силе на наше тело и органе у којима су садржане (Штрбац), те је постулисана и генеричка метафора за емоције ЕМОЦИЈЕ СУ МАТЕРИЈА/ФЛУИД У САДРЖАТЕЉУ ${ }^{6}$ (Кевечеш 2010: 108).

У анализираној грађи утврђен је још један фразеологизам са потпуном еквивалентношћу нем. jmdm schnürt sich das Herz zusammen и срп. свило се око сриа некоме са значењем „растужити се, ражалостити се”. Субјекат осећа превелику тугу, жалост, душевни бол. На сличан начин као и претходни настао је фразеолошки пар са незнатном лексичком разликом нем. jmdm krampft sich das Herz zusammen и срп. срие (душа) се стеже/стегло некоме са значењем „осећати превелику тугу, жалост, душевни бол”.

За немачки фразеологизам das Herz dreht sich mir im Leibe herum Mразовић/Приморац као еквивалент наводе [разг.] срие ми се цепа, кида; ужаснут сам са значењем „бити ожалошћен, несрећан, осећати јаку душевну бол”. У питању су парцијални семантички еквиваленти јер не почивају на истој слици: у немачком језику срце се окреће у телу и концептуализовано је као БИЋЕ, док се у српском концептуализује као ПРЕДМЕТ или ОБЈЕКАТ. Срце поимамо као ЖИВО БИЋЕ које се премеће, помера услед атака негативне емоције, ${ }^{7}$ па је постулисана појмовна метафора СРЦЕ ЈЕ ЖИВО БИЋЕ КОЈИ СЕ ПОМЕРА метонимијски утемељена.

У фразеолошком фонду немачког језика утврдили смо два синонимна фразеологизма нем. es schneidet jmdm ins Herz и es zerreißt jmdm das Herz. Мразовић/Приморац наводе за нем. фразеологизам es schneidet jmdm ins Herz као еквивалент срие ми се кида, цеna. Ми смо за фразеологизам нем. es zerreißt jmdm das Herz установили парцијални еквивалент срп. пара се срие некоме, односно еквиваленте кида/иеепа/ломи/се срие некоме (од туге, жалости и сл.) у

${ }^{6}$ Метафору ЕМОЦИЈЕ СУ МАТЕРИЈА, ЕМОЦИЈЕ СУ МАТЕРИЈА У САДРЖАТЕЉУ И ЕМОЦИЈЕ СУ ТЕЧНОСТ бележи Кликовац (2000: 44, 192, 356). Когнитивисти човека схватају као посуду са ограниченом површином и ограниченим кретањем. Неке концептуалне метафоре заједничке су свим емоцијама нпр: ЕМОЦИЈА ПОСТОЈИ У ЗАТВОРЕНОМ ПРОСТОРУ, а тело је посуда/садржатељ за емоције, у њој се налазе органи који опет имају свој сопствени ритам, а емоције су нападачи, тј. непријатељи: нападају органе, ремете њихов рад, оштећују их и уништавају.

${ }^{7}$ Упоредити са фразеологизмом срие ми је на месту који је карактеричан за позитивне емоције, нпр. срећу. 
значењу „осећати велику душевну бол, бити тужан, жалостан”. Мотивисани су болом који човек може осетити у грудима када је захваћен таквим емоцијама. У српском језику утврђен је још један фразеологизам са сличном позадинском сликом и семантиком срие се чупа из груди некоме за доживљаоца који веома је несрећан, жалостан и осећа јак душевни бол или саосећа с неким.

Фразеологизми са глаголским компонентама сломити, парати, убости/ погодити означавају иницирање туге и сродних негативних емоција у другом учеснику. Немачки фразеологизам jmdm das Herz brechen (js. Herz brechen) и срп. сломити/ломити/разбити некоме срие са значењем „учинити некога несрећним, веома растужити некога, задавати некоме душевну бол" представљају каузативну варијанту фразеологизма jmdm bricht das Herz (vor Kummer) и срп. пуца /препукло је срие некоме са значењем ,јако се ражалостити, растужити, осећати јак душевни бол, умрети од туге". Парцијални еквиваленти нем. jmdm das Herz zerreißen и парати коме срие такође су каузативна варијанта фразеологизма нем. es zerreißt jmdm das Herz и срп. пара се срие некоме, односно кида/иепа/ломи/се срие некоме (од туге, жалости и сл.). У мотивационој слици парања и резања наилазимо и на нож чиме се интензивира семантика фразеологизама, а срце се концептуализује као објекат/предмет.

За наредна два фразеологизма jdm einen Stich ins Herz geben и jmdn ins Herz treffen постоје у српском језику парцијални еквиваленти са морфо-лексичким разликама, односно лексичким разликама, али са истом семантиком убости/ранити некога у срие са значењем „повредити, ожалостити некога, али и увредити некога".

У фразеологизмима са глаголским компонентама ломити, (с)ломити и парати некоме срие, срце се концептуализује као осетљив предмет којим је могуће манипулисати и то појмовном метафором СРЦЕ ЈЕ ОСЕТЉИВ ПРЕДМЕТ и појмовним метонимијама СРЦЕ ЗА ОСЕЋАЈЕ/ЧОВЕКА (Нимајер 2003: 199) Емоција туге концептуализована је укрштеним појмовним метафорама ТУГА ЈЕ НАСИЛНИЧКА ФИЗИЧКА СИЛА ИЛИ НЕПРИЈАТЕЉ/ЕНТИТЕТ КОЈИ ФИЗИЧКИ НАСИЛНО ДЕЛУЈЕ НА СУБЈЕКТА И ТУГА ЈЕ ФИЗИЧКА БОЛ, што је разрада концептуалне метафоре ЕМОЦИОНАЛНО ОШТЕЋЕЊЕ JЕ ФИЗИЧКО ОШТЕһЕЊЕ (Кевечеш 2003a: 46). За фразеологизме убости/ погодити/ранити некога у срце постулисане су укрштене појмовне метафоре ТУГА ЈЕ НАПАД НЕПРИЈАТЕЉА/ФИЗИЧКА ПОВРЕДА И ТУГА ЈЕ ФИЗИЧКА БОЛ (Кевечеш 1986: 85).

3.6. ТУГА ЈЕ БОЛЕСТ. Појмовна метафора ТУГА ЈЕ БОЛЕСТ део је генеричке метафоре ЕМОЦИЈЕ СУ БОЛЕСТ И ЕМОЦИЈЕ СУ НЕДОСТАТАК ВИТАЛНОСТИ, а темељи се на пресликавању ЕМОТИВНИ БОЛ ЈЕ ФИЗИ- 
ЧКИ БОЛ ${ }^{8}$. Драгићевић (2006: 312) сматра да се туга разумева као бол и то пре свега болест срца и душе. Телесни бол лоциран је у срцу, те су и фразеологизми ове групе формирани искључиво око соматизма срце: за нем. фразеологизам jmdm tut das Herz im Leibe weh утврдили смо парцијални лексички фразеологизам у српском боли некога срие. У односу на немачки фразеологизам српски је нешто редукован јер недостаје локација у телу. СРЦЕ метонимијски стоји за човека, а постулисане су и појмовна метафора која почива на метонимији СРЦЕ JЕ МЕСТО ЗА ОСЕЋАЈЕ (Нимајер 2003: 199) и појмовне метафоре ТУГА ЈЕ БОЛЕСТ И ТУГА ЈЕ ФИЗИЧКА БОЛ (Кевечеш 1986: 85).

У немачком језику постоји фразеологизам jmdm blutet das Herz за кога Матешић (538 стр) наводи еквивалент боли некога срие. Мразовић/Приморац за исти фразеологизам наводе као еквивалент фразеологизме срие му се цела, кида; душа га боли. Ми смо мишљења да би адекватан био и еквивалент имати рану на сриу, јер у оба примера можемо постулисати исте појмовне механизме СРЦЕ ЈЕ ЖИВО БИЋЕ КОЈЕ КРВАРИ, СРЦЕ ЈЕ ОРГАН КОЈИ КРВАРИ И ТУГА ЈЕ БОЛЕСТ/БОЛ.

4. ЗАКљУЧАК. У раду је разматрана концептуализација примарне емоције туге у немачким и српским соматским фразеологизмима. Примарни циљ рада представља идентификовање и анализу концептуалних механизама у основи оваквих израза, а секундарни утврђивање типова еквивалентности на семантичком и формалном нивоу. Анализирани корпус лексикографског је карактера и ексцерпиран из одговарајућих семасиолошких и ономасиолошких речника. Анализа је показала оно што смо и очекивали - да се туга концептуализује слично у оба језика и то у структурним појмовним метафорама као ТЕРЕТ, ТАМА и СМРТ, затим у онтолошким као НАСИЛНИЧКА ФИЗИЧКА СИЛА, НЕПРИЈАТЕЉ, ЕНТИТЕТ КОЈИ ФИЗИЧКИ НАСИЛНО ДЕЛУЈЕ НА СУБЈЕКТА, МАТЕРИЈА/ФЛУИД У ПУНОЈ ПОСУДИ и као БОЛЕСТ и БОЛ. Оријентациона метафора ТУГА ЈЕ ДОЛЕ постулисана је и у немачком и српском језику. Већина метафора утемељена је на метонимији, што је и разумљиво, јер су фразеологизми углавном формирани око соматизма срце које метонимијски стоји за човека и за осећаје, а концептуализује се као ПРЕДМЕТ, као место за осећаје, тј. ПОСУДА у којој се налазе емоције и која пуца, кида се, цепа, али и као ЖИВО БИЋЕ КОЈЕ СЕ ПОМЕРА (само у немачком језику), затим КОЈЕ КРВАРИ и ОРГАН КОЈИ КРВАРИ. КонТрастивном анаЛизом утврђени су фразеологизми са потпуном, нултом и парцијалном еквивалентношћу (најзаступљенија група у раду). Анализа је показала још да немачки и српски фразеологизми утемељени на метафоричким и метонимијским пресликавањима указују на одређене сличности у наивној слици света, иако постоје и незнатне културолошки условљене разлике, што потврђује наша

\footnotetext{
${ }^{8}$ Болест као изворни домен типичан је за негативне емоције.
} 
очекивања и иде у прилог тези о универзалности концептуалне метафоре. Рад представља полазиште за даља немачко-српска контрастивна и когнитивна истраживања.

\section{ЛИТЕРАТУРА}

\section{Извори}

Вајнбергер 2012: H. Weinberger, Kroatisch/Serbisch-Deutsches phraseologisches Wörterbuch, angeordnet nach semantischen Gruppen, Wien, Facultas Verlags- und Buchhandels AG.

Дуден 2012: Redensarten. Mannheim, Zürich: Dudenverlag.

Оташевић 2012: Ђ. Оташевић, Фразеолошки речник српског језика, Нови Сад: Прометеј.

PМC 1971-1976: Речник српскохрватскога књижевног језика, I-III. Нови Сад - Загреб: Матица српска - Матица хрватска, 1967-1969. IV-VI. Нови Сад: Матица српска.

PCJ 2011: Речник српскога језика, Нови Сад: Матица српска.

Матешић 1982: J. Matešić Frazeološki rječnik hrvatskoga ili srpskog jezika, Zagreb: Školska knjiga.

Матешић 1982: J. Matešić Hrvatsko-njemački frazeološki rječnik, Zagreb: Nakladni zavod Matice hrvatske, 1982.

Милер 2005: K. Müller, Lexikon der Redensarten, Herkunft und Bedeutung deutscher Redewendungen. München: Basserman Verlag

Мразовић/Приморац 1981: P. Mrazović i R. Primorac, Nemačko-srpskohrvatski frazeološki rečnik, Beograd: Narodna knjiga.

Рерих 1991-1992: L. Röhrich, Das große Lexikon der sprichwörtlichen Redensarten, Band 1, 2, 3. Freiburg im Breisgau: Herder Verlag.

Шеман 1991: H. Schemann, Synonymwörterbuch der deutschen Redensarten, Stuttgart: Ernst Klett Verlag fur Wissen und Bildung. xxxvi.

\section{Цитирана литература}

Барселона 2000: A. Barcelona, (Ed) Metaphor and Metonymy at the Crossroads - A Cognitive Perspective, Berlin/New York: Mouton de Gruyter.

Барселона 2003a: A. Barcelona, On the plausibility of claiming a metonymic motivation for conceptual metaphor, u: Barcelona, A. (ur.) Metaphor and Metonymy at the Crossroads: A Cognitive Perspective. Berlin, New York: Mouton de Gruyter. str. 31-58 
Барселона 2003б: A. Barcelona, Clarifying and applying the notions of metaphor and metonymy within cognitive linguistics, u: Barcelona, A. (ur.) Metaphor And Metonymy in Comparison and Contrast. Berlin/New York: Mouton de Gruyter. str. 207-277.

Бургер/Бухофер/Сиалн 1982: H. Burger, A. Buhofer, A. Sialn et al. Handbuch der Phraseologie. Berlin; New York: Walter de Gruyter.

Доброволскиј 1995: D. Dobrovol'skij, Kognitive Aspekte der Idiom-Semantik, Studien zum Thesaurus deutscher Idiome, Tübingen: Gunter Narr Verlag.

Доброволскиј 1997: D. Dobrovol'skij, Idiome im mentalen Lexikon, Trier: Wissenschaftlicher Verlag.

Доброволскиј/Пираинен 2009: D. Dobrovol'skij / E. Piirainen, Zur Theorie der Phraseologie, kognitive und kulturelle Aspekte, Tübingen: Stauffenburg Verlag.

Драгићевић 2006: Р. Драгићевић, Концептуализације туге у српском језику, Српски језик број 11/1-2, година XI, Београд.

Драгићевић 2007: Р. Драгићевић, Лексикологија српског језика, Београд: Завод за уџбенике.

Екман 2011: Pol Ekman, Razotkrivene emocije, Beograd: Zavod za udžbenike.

Кевечеш/Сабо 1997: Z. Kövecses, P. Szabo, Idioms: A View from Cognitive Semantics, Applied Linguistcs 17 (3) 326-355.

Кевечеш 2003: Z. Kövecses, Metaphor and Emotion: Language, Culture, and Body: Human Feeling, Cambridge, New York: Cambridge University Press.

Кевечеш 2010: Z. Kövecses, Metaphor. A Practical Introduction, New York: Oxford University Press.

Кликовац 2004: D. Klikovac, Metafore u mišljenju i jeziku, Beograd: Biblioteka $\mathrm{XX}$ vek.

Лејкоф/Џонсон 1980: G. Lakoff, M. Johnson, Metaphors We Live By. Chicago: The University of Chicago Press.

Лејкоф 1987: G. Lakoff, Women, fire and dangerous things: what categories reveal about the mind, Chicago: The University of Chicago Press.

Лејкоф 1993: G. Lakoff, The contemporary theory of metaphor, In A. Ortony (ed.) Metaphor and Thought, Cambridge: Cambridge University Press, 202-252. 
Лејкоф/Џонсон 2007: G. Lakoff, M. Johnson, Leben in Metaphern. Konstruktion und Gebrauch von Sprachbildern, Übersetzung der deutschen Ausgabe von Astrid Hildebrand,Fünfte Auflage, Heidelberg: CarlAuer-Systeme-Verlag.

Мршевић Радовић 1987: Д. Мршевић-Радовић, Фразеолошке глаголско-именичке синтагме у савременом српскохрватском језику, Београд: Филолошки факултет.

Мушовић 2002: А. Мушовић, Соматске фразеолошке јединице за изражавање емоиија и њихова синтаксичка функиија, Косовска Митровица: Филозофски факултет.

Нимајер 2003: S. Niemeier, Straight from the heart-metonymic and metaphorical explorations. U: A. Barcelona (ur.). Metaphor and Metonymy at the Crossroads: A Cognitive Perspective. Berlin, New York: Mouton de Gruyter. str. 195-213.

Раздобудко Човић 2003: Л. Раздобудко-Човић, Семантика и прагматика соматизама у српском и руском језику, Београд: Ведес.

Ристић 2013: G. Ristić, Frazeologizmi gestovno-mimičke motivacije za izražavanje emocija u nemačkom i srpskom jeziku. Zbornik radova sa Šestog međunarodnog interdisciplinarnog simpozijuma Susret Kultura, 369-378.

Хосенс 1990: L. Goossens, Metaphtonymy: The Interaction of Metaphor and Metonymy in Figurative Expressions for Linguistic Action, Cognitive Linguistics Volume 1, Issue 3 323-342.

Хрњак 2005: A. Hrnjak, Geste i mimika kao izvori frazeologije (na primjeru hrvatske frazeologije), Filologija 44, 29-50.

Чен 2007: L. Chen, Bilder menschlicher Emotionen in deutschen und chinesischen Phrasemen, Phraseologie und Parämiologie, Band 22.

Штрбац 2018: Г. Штрбац, Фразеологија о човеку и човек у фразеологији, Нови Сад: Филозофски факултет. 


\section{KONZEPTUALISIERUNG VON DER TRAURIGKEIT IN DEUTSCHEN UND SERBISCHEN SOMATISCHEN PHRASEOLOGISMEN}

\section{Zusammenfassung}

In diesem Beitrag wurde die Konzeptualisierung von der Primäremotion Traurigkeit in deutschen und serbischen somatischen Phraseologismen analysiert. Die aus entsprechenden phraseologischen Wörterbüchern exzerpierten deutschen und serbischen Somatismen bilden das Korpus. Die kognitive Metapherntheorie von Lakoff/Johnson wird als die theoretische Grundlage angesehen. Bei der Versprachlichung der Emotionen spielen Phraseologismen und Metaphern eine besondere Rolle. Den untersuchten Traurigkeit - Somatismen liegen folgende konzeptuelle Metaphern zugrunde: TRAURIGKEIT IST LAST / DUNKEL / TOD / UNTEN/ KRANKHEIT/SCHMERZ/ PHYSISCHE KRAFT /FEIND/ ENTITÄT IM GEFÄSS / BESCHÄDIGUNG DES GEFÄSSES. Der Somatismus Herz wird konzeptualisiert als OBJEKT/ GEFÄSS / LEBEWESEN und DAS BLUTENDE ORGAN. Die Ergebnisse der kontrastiven Analyse sind die Voll-, Null- und Teiläquivalenz (mit lexikalischen, morphologischen und morphosyntaktischen Unterschieden).

Die konzeptuelle Analyse hat ergeben, dass die Traurigkeit in beiden Sprachen sehr ähnlich dargestellt wird. Der hohe Grad an Übereinstimmung mag wohl aus dem universellen Charakter der dargestellten Metaphern resultieren.

Schlüsselwörter: Somatismus, kontrastive und konzeptuelle Analyse, Äquivalenz, konzeptuelle Metapher ud Metonymie. 